\title{
RESPONSE OF Gardenia jasminoides PLANTS GROWN ON VARIOUS GROWING MEDIA TO ORGANIC AMENDMENTS
}

(Received: 3.9.2020)

\author{
By \\ Fawzia Gh. Zenna and Y. I. Mahmoud *

\begin{abstract}
Botanical Gardens Research Department, Horticulture Research Institute, and * Soils, Water and Environment Research Institute, Agricultural Research Center, Giza
\end{abstract}

\begin{abstract}
This investigation was conducted during two successive seasons of 2017 and 2018 to evaluate the efficacy of compost tea types prepared from different organic sources including filter mud, spent mushroom compost and vermicompost as well as the most suitable growing media on growth behavior and blooming of gardenia plants. The results showed that all organic fertilizers applied for Gardenia jasminoides plants grown in the mixture of sand and peat moss $(1: 2 \mathrm{v} / \mathrm{v})$ had the best results in comparison with the control plants grown in other growing media. Application of vermicompost tea fertilizer significantly improved all vegetative growth traits i.e. plant height, stem diameter, numbers of branches and leaves as well as increased leaf contents of total chlorophyll and elements of nitrogen, phosphorus and potassium. This reflected on producing flowers with good quality attributes of the plants. The highest populations of total bacteria, fungi and actinomycetes and dehydrogenase activity in the rhizosphere soil were attained by the application of vermicompost tea fertilizer for plants grown in sand and peat moss mixture.
\end{abstract}

Key wrds: Gardenia jasminoides, peat moss, compost tea, NPK Fertilization.

\section{INTRODUCTION}

Gardenia jasminoides is a fragrant flowering evergreen tropical shrub that belongs to the Rubiaceae family, characterized by glossy, bright green leaves and large double white highly fragrant flowers, cultivated in multiple areas in gardens worldwide (Bailey, 1969). Apart from the difficulties in creating the suitable conditions for the plant to live, gardenias need to be planted in an acidic soil (it is an acidophilic plant). It needs a moist soil with good drainage and desirable $\mathrm{pH}$ between 4.5 5.5 (Soliman et al., 2013). It grows in many temperate regions (Gilam, 1999). It is not only used as natural yellow dyes for many years (Hong et al., 2015), but also has various biological activities, such as anti-inflammatory (Lim et al., 2008), anti-diabetic (Wu et al., 2009), anti-depression (Tao et al., 2014), improvement of the quality of sleep (Kuratsune et al., 2010) and antioxidant properties (Debnath et al., 2011). A number of chemical components of G. jasminoides have been isolated and characterized, including iridoids, iridoid glucosides, triterpenoids, organic acids, and volatile compounds. Geniposide, genipin, gardenoside, crocin, and iridiod are the major bioactive compounds found in G. jasminoides. For instance, the yield of geniposide reached $10.9 \%$ under certain extraction conditions (Yang et al., 2009).

Using chemical fertilizers in agricultural production contaminates the soil and underground water. The movement of agrochemicals through soil to groundwater or their discharge to surface water represents an ecological risk (Allinson et al., 2000). They also accumulate in food chain causing hazardous effects (Hegazi et al., 2010).

Many solutions were suggested to reduce the chemical fertilizer problems, one of which is using organic fertilizers such as composts, which are low in costs and friendly environmental amendments. Composts applied to the soil, improves its quality by altering its chemical and physical properties, increasing organic matter content, water holding capacity, the overall diversity of microbes, providing macro and micro nutrients essential for plant growth and suppressing diseases, which indirectly contribute 
to plant growth enhancement (Heather et al., 2006).

Compost tea is one of the alternative techniques extracted from composted materials by steeping or brewing the compost in water using various preparation methods (Ingham, 2005). It has been cited as an option for conventional and organic growers thought to enhance crop fertility by introducing microorganisms that might aid in soil nutrient retention and extraction, and by adding soluble nutrients, further adding to their potential value as a part of an integrated crop management plan (Kannangara et al., 2006).

Filter mud compost, also called filter-cake, is the waste product in vacuum and press filters of the sugar industry which is about 3-8\% of processed sugarcane that can be used to increase organic material on the ground and provide benefits for the soil and plants (Jamil et al., 2008).

Spent mushroom compost (SMC), otherwise known as the spent mushroom substrates, is the remains of the compost in which mushrooms are produced (McCahey et al., 2003). It is composed of fungal mycelia, extracellular enzymes (such as cellulase and xylanase) secreted from mushrooms for degradation of substrates, and unused lignocellulosic substrates (Fasidi et al., 2008). In field crop production, the principal uses of SMC are as an organic fertilizer and as a soil conditioner for enhancing physical and/or chemical properties of soil (Courtney and Mullen, 2008).

Vermicompost is a product derived from the accelerated biological degradation of organic wastes by earthworms and microorganisms (Arancon and Edwards 2005). Vermicompost improves soil aeration and texture thereby reducing soil compaction, enhances water retention capacity of soil because of its high organic matter content and also promotes better root growth, nutrient absorption and improves nutrient status of soil, both macro- and micronutrients (Chauhan and Singh, 2013).

Growing media, otherwise known as the plant substrates, are used to describe the materials used to grow plants in containers (Schroeder and Sell, 2009). A good growing medium provides a root environment that is initially free of plant pathogens and properties that ensure an adequate aeration, water, and nutrient supply (Savvas and Gruda, 2018).

Thus, the goal of the present study was to evaluate the efficacy of aerated compost teas prepared from filter mud, spent mushroom compost and vermicompost as the most suitable growing media on growth promotion and blooming of Gardenia jasminoides plant.

\section{MATERIALS AND METHODS}

\subsection{Plant material}

One hundred thirty-five uniforms and healthy Gardenia jasminoides plants with an average length of $12 \mathrm{~cm}$ resulting from tissue culture after their adaptation in a greenhouse shaded at the nursery of Horticulture Research Institute, Agricultural Research Center, Giza, Egypt were used. Plants were transplanted on the first week of October in pots of $18 \mathrm{~cm}$ diameter containing different mixtures of peat moss and sand. All pots had bottom holes to allow excess water drainage.

\subsection{Experimental lay out}

The experiment was designed as a split plot with three replications in randomized complete blocks. The main plots were devoted to five organic fertilizer types; control (negative control), mineral NPK fertilizer (positive control), filter mud tea, spent mushroom compost tea and vermicompost tea and the sub plots were occupied by different growing media types containing three mixtures of sand and peat moss $(1: 1,1: 2$ and $2: 1 \mathrm{v} / \mathrm{v})$.

* Control (un treated plants)

* Mineral NPK fertilizer (20:20:20) applied after one month from transplanting at a rate of 2 g/pot every two weeks until reaching the flowering stage.

* Organic fertilizer types included filter mud tea, spent mushroom compost tea and vermicompost tea.

* Compost teas extracted from the previous three different compost sources by completely submerging the respective compost in containers, in the ratio of 1: $10(\mathrm{w} / \mathrm{v})$ in tap water amended with $0.5 \%(\mathrm{v} / \mathrm{v})$ molasses are shown in Table (A) as described by Shrestha et al. (2018). All compost teas were added as 100 $\mathrm{ml} / \mathrm{plant}$ after one month of adaptation and added continuously each two weeks till flowering stage.

* All plants were treated with chelated ferrous at the rate of $150 \mathrm{ppm}$ every month along the growing season

* Analysis of peat moss and sand media were shown in Tables (A\&B).

The following measurements were estimated at the end of each experimental season (2017, 2018): 
1.Vegetative growth characteristics: Plant height (cm), stem diameter $(\mathrm{cm})$, number of branches and number of leaves/plant.

2. Plant biomass characteristics: Stem fresh and dry weights $(\mathrm{g})$ and root fresh and dry weight (g).

3. Flowering parameters: Flowering date, flowering plants (\%), number of flowers/plant and fresh weight of flowers $(\mathrm{g})$.

4. Leaf content of pigments: Chlorophyll a, b and total chlorophyll (Westein, 1957).

5. Leaf and soil contents of mineral elements

* Total nitrogen (\%):using the Kjeldahl method according to the method adopted by Pregl (1945).

* Phosphorus (\%):using spectrophotometer according to the method described by Snell and Snell (1967)

* Potassium (\%): using flame photometer
* The plate count technique using the suitable serial dilutions and specific media was applied for estimation of the examined microbial groups (total bacteria, fungi and actinomycetes) after one year (Defico Manual, 1989).

* Dehydrogenase enzyme activity was assed according to Casida et al. (1964).

\subsection{Experimental design and statistical analysis}

The experiment was designed as a split plot with three replications in randomized complete blocks. The statistical analysis of the present data was carried out according to Snedecor and Cochran (1980). Averages were compared using the L.S.D. values at 5\% level (Steel and Torrie, 1980).

Table (A): Physical, chemical and biological properties of compost teas and peat moss media.

\begin{tabular}{|c|c|c|c|c|c|}
\hline \multicolumn{2}{|r|}{ Parameters } & $\begin{array}{c}\text { Filter mud } \\
\text { tea }\end{array}$ & $\begin{array}{l}\text { Spent mushroom } \\
\text { compost tea }\end{array}$ & $\begin{array}{c}\text { Vermi- } \\
\text { compost tea }\end{array}$ & $\begin{array}{l}\text { Peat- } \\
\text { moss }\end{array}$ \\
\hline \multirow{5}{*}{ 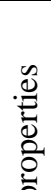 } & Density $\left(\mathrm{Kg} / \mathrm{m}^{3}\right)$ & 535 & 70 & 700 & 175 \\
\hline & Moisture content $(\%)$ & 34 & 7 & 74 & 80 \\
\hline & $\mathrm{pH}(1: 10)(\%)$ & 7.44 & 7.66 & 7.63 & 4.30 \\
\hline & EC $(1: 10)\left(\mathrm{dSm}^{-1}\right)$ & 3.80 & 2.36 & 1.33 & 0.30 \\
\hline & Total nitrogen $(\%)$ & 1.53 & 0.83 & 2.09 & 1.09 \\
\hline \multirow{8}{*}{ 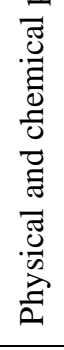 } & Ammoniacel nitrogen (ppm) & 84 & 700 & 56 & 70 \\
\hline & Nitrate nitrogen (ppm) & 264 & 840 & 160 & 30 \\
\hline & Organic matter $(\%)$ & 45.19 & 61.94 & 64.33 & 90.00 \\
\hline & Organic carbon $(\%)$ & 26.21 & 35.93 & 37.31 & 52.20 \\
\hline & Ash (\%) & 54.81 & 38.06 & 35.67 & 10.00 \\
\hline & $\mathrm{C} / \mathrm{N}$ ratio & $17: 1$ & $34: 1$ & $18: 1$ & $48: 1$ \\
\hline & Total phosphorus $\left(\mathrm{P}_{2} \mathrm{O}_{5}\right)(\%)$ & 4.60 & 0.40 & 2.42 & 0.23 \\
\hline & Total potassium $\left(\mathrm{K}_{2} \mathrm{O}\right)(\%)$ & 0.41 & 0.80 & 0.76 & 1.70 \\
\hline \multirow{3}{*}{ 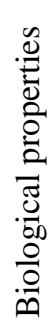 } & Total bacteria (CFU/g) & $8 \times 10^{6}$ & $2 \times 10^{6}$ & $5 \times 10^{6}$ & $5 \times 10^{2}$ \\
\hline & Total fungi (CFU/g) & $9 \times 10^{3}$ & $3 \times 10^{3}$ & $6 \times 10^{3}$ & $1 \times 10^{1}$ \\
\hline & Total actionmysetes (CFU/g) & $11 \times 10^{3}$ & $7 \times 10^{3}$ & $4 \times 10^{3}$ & $2 \times 10^{2}$ \\
\hline
\end{tabular}

Results were calculated on oven dry basis.

Table (B): Physical and chemical properties of sandy soil sample.

\begin{tabular}{|c|c|c|c|c|c|c|c|c|c|c|}
\hline \multicolumn{7}{|c|}{ Physical properties } & \multicolumn{7}{|c|}{ Chemical properties } \\
\hline $\begin{array}{c}\text { pH (1:10) } \\
(\%)\end{array}$ & $\begin{array}{c}\mathbf{E C ~ ( 1 : 1 0 )} \\
(\mathbf{d S m})\end{array}$ & $\mathbf{C a}^{\mathbf{+ 2}}$ & $\mathbf{M g}^{\mathbf{+ 2}}$ & $\mathbf{K}^{+}$ & $\mathbf{N a}^{+}$ & $\mathbf{C O}$ & $\mathbf{H C O}$ & $\mathbf{C l}^{\mathbf{3 -}}$ & $\mathbf{S O}_{\mathbf{4}}^{--}$ & $\begin{array}{c}\mathbf{S P} \\
\mathbf{\%}\end{array}$ \\
\hline 8.4 & 8.12 & 18.4 & 2.23 & 0.35 & 74 & 0.0 & 1.42 & 46.6 & 46.98 & 24 \\
\hline
\end{tabular}

according to the method described by Jackson (1967).

6. Biological activities in rhizospher soil of gardenia plants
3. RESULTS AND DISCUSSION 3.1. Vegetative growth characteristics

Data presented in Table (1) show that application of organic fertilizers and different 
growing media either alone or in combination significantly improved all vegetative growth characteristics.

The highest significant values of all vegetative growth characteristics were attained by vermicompost tea fertilizer and filter mud tea and spent mushroom compost tea then mineral NPK fertilizer, while control plants resulted in significantly the least values in both seasons.

Plants grown in sand + peat $(1: 2)$ had significantly the highest values of those parameters followed by sand + peat $(1: 1)$. On the other hand, sand + peat (2:1) exhibited in significantly the least values in both season.

Application of vermicompost tea fertilizer for plants grown in sand + peat (1:2) had significantly the highest values of all parameters, while control plants grown in sand + peat $(2: 1)$ resulted in significantly the least values in both seasons.

These results are in accordance with those obtained by Putra et al. (2016) and Rahmad et al. (2019) on filter mud tea; Roy et al. (2015) and Wiafe-Kwagyan and Odamtten (2018) on spent mushroom compost tea. Tejada and Benítez (2015) and Mondal et al. (2017) on vermicompost tea, they found that these organic fertilizers promoted plant vegetative growth traits.

The utilization of various mineral elements present in the spent mushroom compost tea, may

Table (1): Effects of organic fertilizers and growing media on vegetative growth characteristics of Gardenia jasminoides during 2017 and 2018 seasons.

\begin{tabular}{|c|c|c|c|c|c|c|c|c|}
\hline \multirow{4}{*}{$\begin{array}{c}\text { Organic } \\
\text { fertilizers (A) }\end{array}$} & \multicolumn{8}{|c|}{ Growing media- Sand: Peat moss (v/v) (B) } \\
\hline & $1: 1$ & 1:2 & $2: 1$ & Means (B) & 1:1 & 1:2 & $2: 1$ & Means (A) \\
\hline & \multicolumn{4}{|c|}{ First season } & \multicolumn{4}{|c|}{ Second season } \\
\hline & \multicolumn{8}{|c|}{ Plant height (cm) } \\
\hline Control & 35.3 & 39.3 & 34.3 & 36.3 & 40.4 & 45.0 & 39.3 & 41.6 \\
\hline NPK & 46.3 & 46.4 & 42.4 & 45.0 & 53.0 & 53.1 & 48.5 & 51.6 \\
\hline Filter mud tea & 49.8 & 51.4 & 45.9 & 49.0 & 57.1 & 58.8 & 52.6 & 56.1 \\
\hline $\begin{array}{l}\text { Spent mushroom } \\
\text { compost tea }\end{array}$ & 46.7 & 48.8 & 45.4 & 47.0 & 53.4 & 55.9 & 52.0 & 53.8 \\
\hline Vermicompost tea & 49.6 & 55.8 & 47.1 & 50.9 & 56.8 & 63.9 & 54.0 & 58.2 \\
\hline Means (B) & 45.5 & 48.3 & 43.0 & & 52.2 & 55.4 & 49.3 & \\
\hline \multirow[t]{2}{*}{ LSD 5\% } & $\mathrm{A}=4.4$ & $\mathrm{~B}=3.4$ & $\mathrm{AB}=7.6$ & & $\mathrm{~A}=5.1$ & $\mathrm{~B}=3.9$ & $\mathrm{AB}=8.8$ & \\
\hline & \multicolumn{8}{|c|}{ Stem diameter $(\mathrm{cm})$} \\
\hline Control & 0.78 & 0.81 & 0.77 & 0.78 & 0.89 & 0.93 & 0.88 & 0.90 \\
\hline NPK & 1.07 & 1.03 & 0.84 & 0.98 & 1.22 & 1.18 & 0.97 & 1.12 \\
\hline Filter mud tea & 0.98 & 1.23 & 0.96 & 1.06 & 1.13 & 1.40 & 1.10 & 1.21 \\
\hline $\begin{array}{l}\text { Spent mushroom } \\
\text { compost tea }\end{array}$ & 0.94 & 1.10 & 0.91 & 0.98 & 1.08 & 1.26 & 1.04 & 1.13 \\
\hline Vermicompost tea & 1.10 & 1.27 & 1.10 & 1.16 & 1.26 & 1.45 & 1.26 & 1.32 \\
\hline Means (B) & 0.97 & 1.09 & 0.92 & & 1.11 & 1.24 & 1.05 & \\
\hline \multirow[t]{2}{*}{ LSD 5\% } & $\mathrm{A}=0.08$ & $\mathrm{~B}=0.07$ & $\mathrm{AB}=0.15$ & & $\mathrm{~A}=0.10$ & $\mathrm{~B}=0.08$ & $\mathrm{AB}=0.17$ & \\
\hline & \multicolumn{8}{|c|}{ No. of branches } \\
\hline Control & 7.00 & 6.43 & 5.43 & 6.29 & 8.02 & 7.36 & 6.22 & 7.20 \\
\hline NPK & 7.50 & 7.53 & 7.17 & 7.40 & 8.59 & 8.62 & 8.21 & 8.47 \\
\hline Filter mud tea & 8.30 & 8.47 & 8.13 & 8.30 & 9.50 & 9.70 & 9.31 & 9.50 \\
\hline $\begin{array}{l}\text { Spent mushroom } \\
\text { compost tea }\end{array}$ & 8.20 & 8.23 & 7.87 & 8.10 & 9.39 & 9.43 & 9.01 & 9.28 \\
\hline Vermicompost tea & 8.73 & 9.23 & 8.57 & 8.84 & 10.00 & 10.57 & 9.81 & 10.13 \\
\hline Means (B) & 7.95 & 7.98 & 7.43 & & 9.10 & 9.14 & 8.51 & \\
\hline \multirow[t]{2}{*}{ LSD 5\% } & $A=0.66$ & $\mathrm{~B}=0.51$ & $\mathrm{AB}=1.15$ & & $\mathrm{~A}=0.76$ & $\mathrm{~B}=0.59$ & $\mathrm{AB}=1.31$ & \\
\hline & \multicolumn{8}{|c|}{ No. of leaves } \\
\hline Control & 86.8 & 87.2 & 60.9 & 78.3 & 99.4 & 99.8 & 69.7 & 89.6 \\
\hline NPK & 103.2 & 100.3 & 89.4 & 97.6 & 118.2 & 114.9 & 102.4 & 111.8 \\
\hline Filter mud tea & 111.3 & 123.4 & 110.7 & 115.1 & 127.5 & 141.3 & 126.7 & 131.8 \\
\hline $\begin{array}{l}\text { Spent mushroom } \\
\text { compost tea }\end{array}$ & 80.5 & 121.3 & 108.0 & 103.3 & 92.1 & 138.9 & 123.7 & 118.2 \\
\hline Vermicompost tea & 118.3 & 128.0 & 114.3 & 120.2 & 135.5 & 146.6 & 130.9 & 137.7 \\
\hline Means (B) & 100.0 & 112.1 & 96.7 & & 114.5 & 128.3 & 110.7 & \\
\hline LSD 5\% & $A=16.9$ & $\mathrm{~B}=13.1$ & $\mathrm{AB}=29.3$ & & $\mathrm{~A}=19.4$ & $\mathrm{~B}=15.0$ & $\mathrm{AB}=33.6$ & \\
\hline
\end{tabular}


be directly linked to good plant growth (Jonathan et al., 2011). Moreover, the improvements in growth of plants could be attributed to that vermicomposts contribute to improvements in physico-chemical and biological characteristics of the planting media that favored better plant growth (Arancon and Edwards, 2005). In addition, the presence of a great diversity of microorganisms in vermicompost facilitates nutrient assimilation in roots and promotes plant growth by producing hormones and enzymes (Cabrera et al., 2007). For this reason, vermicompost is considered a plant growth biostimulator and an excellent basis for the establishment of symbiotic and nonsymbiotic beneficial microorganisms (Mondal et al., 2017).

As to growing media, results are in agreement with those obtained by Abd El Gayed and Attia (2018) who found that the maximum beneficial effect on the vegetative

growth characteristics including number of leaves and branches was recorded in Celosia argentea plants grown in peat + sand $(2: 1 \mathrm{v} / \mathrm{v})$.

Peat moss generally tend to possess excellent physical, chemical and biological properties, which reflects on increasing nutrient retention, promoting vegetative growth and improving growth overall through the activity of meristematic tissue (Krucker et al., 2010).

\subsection{Plant biomass characteristics}

As shown in Table (2), all the plant biomass characteristics i.e. fresh and dry weights of the stem and roots were significantly affected by the application of organic fertilizers and different growing media either alone or in combination in both seasons.

The promotion of plant biomass characteristics was associated with using vermicompost tea, spent mushroom compost tea, filter mud tea and mineral NPK fertilizer in descending order, whereas the least were attained by control plants in both seasons.

Plants grown in sand + peat $(1: 2)$ resulted in significantly the highest values of all parameters followed by sand + peat $(1: 1)$, sand + peat $(2: 1)$ had significantly the least values in both seasons.

Application of vermicompost tea for plants grown in sand: peat (1:2) resulted in significantly the highest values of all parameters. On the other hand, control plants grown in sand + peat $(2: 1)$ had significantly the least values in both seasons.

These results are in accordance with those obtained by Putra et al. (2016) and Rahmad et al. (2019) on filter mud tea; Wiafe-Kwagyan \& Odamtten (2018) on spent mushroom compost tea as well as Arancon et al., (2004) and Arancon and Edwards (2005) on vermicompost tea who found that accumulation of plant dry matter increased with increasing organic matter. The present results are in agreement with those obtained by Ercisli et al., (2005) and Cros et al. (2007). They found that the highest stem and root dry weights were obtained from fern strawberry and common purslane plants grown in the peat moss medium.

\subsection{Flowering parameters}

\subsubsection{Flowering date}

Application of vermicompost tea and mineral NPK fertilizer induced early flowering $(179,178$ and 177, 178 days, respectively) followed by filter mud tea and spent mushroom compost tea (185, 186 and 185, 187 days each), while the control plants exhibited late flowering (200 and 204 days) in both seasons.

No significant differences were observed among growing media concerning flowering date in both seasons.

Applications of vermicompost tea and mineral NPK fertilizer for plants grown in sand: peat $(1: 2 \mathrm{v} / \mathrm{v})$ had the earliest flowering date (178, 177 and 176, 177 days, respectively) followed by filter mud tea and spent mushroom compost tea for plants grown in sand: peat (1:2) $(185,184$ and 184, 186 days, respectively), while control plants grown in sand: peat $(2: 1)$ recorded the latest (200 and 204 days) in both seasons.

These results are in accordance with those obtained by Edwards and Burrows (1988) who found that some ornamental plants such as chrysanthemums, salvias and petunias flowered earlier in vermicomposts compared to those grown in control planting media.

\subsubsection{Flowering plants $(\%)$}

The highest significant percentages of flowering plants were attained by vermicompost tea followed by spent mushroom compost tea then filter mud tea. Both the control and mineral NPK fertilizer resulted in significantly the least percentages of flowering plants in both seasons.

Gardenia plants grown in sand + peat $(1: 2)$ had significantly the highest percentage of flowering plants followed by sand + peat $(1: 1)$. On the other hand, sand + peat $(2: 1)$ resulted in significantly the least percentage in both seasons.

Application of vermicompost tea for plants grown in sand + peat (1:2) had significantly the 
Table (2): Effects of organic fertilizers and growing media on plant biomass characteristics of Gardenia Jasminoides during 2017 and 2018 seasons.

\begin{tabular}{|c|c|c|c|c|c|c|c|c|}
\hline \multirow{4}{*}{$\begin{array}{c}\text { Organic } \\
\text { fertilizers (A) }\end{array}$} & \multicolumn{8}{|c|}{ Growing media- Sand: Peat moss (v/v) (B) } \\
\hline & $1: 1$ & $1: 2$ & $2: 1$ & $\begin{array}{l}\text { Means } \\
\text { (B) }\end{array}$ & $1: 1$ & $1: 2$ & $2: 1$ & $\begin{array}{l}\text { Means } \\
\text { (A) }\end{array}$ \\
\hline & \multicolumn{4}{|c|}{ First season } & \multicolumn{4}{|c|}{ Second season } \\
\hline & \multicolumn{8}{|c|}{ Stem fresh weight $(\mathrm{g})$} \\
\hline Control & 23.3 & 28.6 & 22.6 & 24.8 & 26.7 & 32.7 & 25.9 & 28.4 \\
\hline NPK & 31.2 & 36.9 & 29.2 & 32.4 & 35.7 & 42.2 & 33.4 & 37.1 \\
\hline Filter mud tea & 32.7 & 39.9 & 29.0 & 33.9 & 37.4 & 45.7 & 33.2 & 38.8 \\
\hline $\begin{array}{l}\text { Spent mushroom } \\
\text { compost tea }\end{array}$ & 39.3 & 43.3 & 33.5 & 38.7 & 45.0 & 49.6 & 38.4 & 44.3 \\
\hline Vermicompost tea & 47.0 & 54.3 & 41.7 & 47.7 & 53.8 & 62.2 & 47.7 & 54.6 \\
\hline Means (B) & 34.7 & 40.6 & 31.2 & & 39.7 & 46.5 & 35.7 & \\
\hline \multirow[t]{2}{*}{ LSD 5\% } & $A=1.7$ & $\mathrm{~B}=1.3$ & $\mathrm{AB}=2.9$ & & $\mathrm{~A}=1.9$ & $\mathrm{~B}=1.5$ & $\mathrm{AB}=3.4$ & \\
\hline & \multicolumn{8}{|c|}{ Stem dry weight $(\mathrm{g})$} \\
\hline Control & 11.4 & 14.8 & 11.2 & 12.5 & 13.0 & 16.9 & 12.9 & 14.3 \\
\hline NPK & 11.6 & 15.6 & 11.9 & 13.0 & 13.2 & 17.9 & 13.6 & 14.9 \\
\hline Filter mud tea & 15.0 & 18.8 & 14.5 & 16.1 & 17.2 & 21.6 & 16.6 & 18.4 \\
\hline $\begin{array}{l}\text { Spent mushroom } \\
\text { compost tea }\end{array}$ & 18.7 & 21.0 & 15.5 & 18.4 & 21.4 & 24.1 & 17.8 & 21.1 \\
\hline Vermicompost tea & 23.0 & 25.5 & 20.3 & 22.9 & 26.3 & 29.2 & 23.3 & 26.3 \\
\hline Means (B) & 15.9 & 19.2 & 14.7 & & 18.2 & 21.9 & 16.8 & \\
\hline \multirow[t]{2}{*}{ LSD 5\% } & $\mathrm{A}=1.2$ & $\mathrm{~B}=0.9$ & $\mathrm{AB}=2.0$ & & $\mathrm{~A}=1.3$ & $\mathrm{~B}=1.0$ & $\mathrm{AB}=2.3$ & \\
\hline & \multicolumn{8}{|c|}{ Root fresh weight (g) } \\
\hline Control & 21.5 & 26.3 & 18.3 & 22.1 & 24.7 & 30.1 & 21.0 & 25.3 \\
\hline NPK & 22.2 & 28.4 & 19.3 & 23.3 & 25.4 & 32.5 & 22.1 & 26.7 \\
\hline Filter mud tea & 30.0 & 34.0 & 27.6 & 30.5 & 34.4 & 38.9 & 31.6 & 35.0 \\
\hline $\begin{array}{l}\text { Spent mushroom } \\
\text { compost tea }\end{array}$ & 31.7 & 34.7 & 30.3 & 32.2 & 36.3 & 39.7 & 34.7 & 36.9 \\
\hline Vermicompost tea & 35.3 & 37.7 & 33.7 & 35.6 & 40.5 & 43.1 & 38.5 & 40.7 \\
\hline Means (B) & 28.1 & 32.2 & 25.8 & & 32.2 & 36.9 & 29.6 & \\
\hline \multirow[t]{2}{*}{ LSD 5\% } & $\mathrm{A}=1.5$ & $\mathrm{~B}=1.2$ & $\mathrm{AB}=2.7$ & & $A=1.8$ & $\mathrm{~B}=1.4$ & $\mathrm{AB}=3.1$ & \\
\hline & \multicolumn{8}{|c|}{ Root dry weight (g) } \\
\hline Control & 10.1 & 12.4 & 8.4 & 10.3 & 11.6 & 14.2 & 9.6 & 11.8 \\
\hline NPK & 11.0 & 13.7 & 8.7 & 11.1 & 12.6 & 15.7 & 10.0 & 12.7 \\
\hline Filter mud tea & 14.0 & 15.4 & 12.6 & 14.0 & 16.0 & 17.7 & 14.4 & 16.0 \\
\hline $\begin{array}{l}\text { Spent mushroom } \\
\text { compost tea }\end{array}$ & 14.0 & 15.1 & 14.9 & 14.7 & 16.0 & 17.3 & 17.1 & 16.8 \\
\hline Vermicompost tea & 16.9 & 18.2 & 16.6 & 17.2 & 19.4 & 20.8 & 19.0 & 19.7 \\
\hline Means (B) & 13.2 & 15.0 & 12.2 & & 15.1 & 17.1 & 14.0 & \\
\hline LSD 5\% & $\mathrm{A}=1.8$ & $\mathrm{~B}=1.4$ & $\mathrm{AB}=3.1$ & & $\mathrm{~A}=2.1$ & $\mathrm{~B}=1.6$ & $\mathrm{AB}=3.6$ & \\
\hline
\end{tabular}

highest percentage of flowering plants, while mineral NPK fertilizer for plants grown in sand + peat $(2: 1)$ resulted in significantly the least percentage of flowering plants in both seasons.

\subsubsection{Number of flowers/plant}

The promotion of the number of flowers/plant was significantly associated with using vermicompost tea, spent mushroom compost tea and filter mud tea in descending order, whereas the least values occurred by both the control and mineral NPK fertilizer in both seasons.

Plants grown in sand + peat $(1: 2)$ resulted in 
significantly the highest value of the number of flowers/plant followed by sand + peat (1:1), while sand (2:1) had significantly the least value in both seasons.

Application of vermicompost tea for plants grown in sand: peat (1:2) resulted in significantly the highest number of flowers/plant. On the other hand, the control and mineral NPK fertilizer for plants grown in sand + peat $(2: 1)$ had significantly the least values in both seasons.

These results are in accordance with those obtained by Arancon et al. (2008) on petunias plants and Kist et al. (2019) on tomato plants who found that vermicompost produced significantly more flowers compared to inorganic fertilizers.

These results may also be attributed to the presence of plant growth regulating substances (PGRS) in vermicompost, which act directly on the plant physiology, providing more significant growth and development. However, earthworm intestine contains a wide range of microorganisms, enzymes, and hormones that are transferred to vermicompost during the organic waste degradations process (Nagavallemma et al., 2004). These microorganisms can produce PGRS such as auxins, gibberellins, cytokinins, abscisic acid and ethylene in significant amounts (Karadeniz et al., 2006). Among PGRS, the gibberellins are involved in flowering regulations and are essential for the development of fertile flowers in plants (Van Den Heuvel et al., 2002).

As for growing media, the capability of peat moss for increasing flower number/plant was obtained by Basheer and Thekkayam (2012) on Anthurium; Naz et al. (2013) on Antirrhinum majus; Mousa (2015) on Gardenia jasminoides and Abd El Gayed and Attia (2018) on Celosia argentea

\subsubsection{Fresh weight of flowers}

The highest significant value of fresh weight of flowers was attained by Vermicompost tea followed by spent mushroom compost tea, filter mud tea then mineral NPK fertilizer, while the control plants resulted in significantly the least value in both seasons.

Plants grown in sand + peat $(1: 2)$ had significantly the highest value of fresh weight of flowers followed by sand + peat $(1: 1)$. On the other hand, sand + peat $(2: 1)$ resulted in significantly the least value in both seasons.

Aplication of vermicompost tea for plants grown in sand + peat $(1: 2)$ had significantly the highest value of fresh weight of flowers, while the control plants grown in sand + peat (2:1) resulted in significantly the least value in both seasons.

The role of NPK in increasing flowers weight was mentioned by Abdou (2002) on borage; Sayed (2004) and Dongardive et al. (2007) on gladiolus.

The capability of peatmoss in increasing flowers weight was attained by Basheer and Thekkayam (2012) on Anthurium; Naz et al. (2013) on Antirrhinum majus; Mousa (2015) on Gardenia jasminoides and Abd El Gayed and Attia (2018) on Celosia argentea.

\subsection{Leaf contents of pigments}

\subsubsection{Chlorophyll (a)}

The highest significant value of leaf content of chlorophyll (a) was attained by mineral NPK fertilizer and vermicompost tea, by spent mushroom compost tea then filter mud tea. Control plants exhibited significantly the least value of chlorophyll a in both seasons. No significant differences were observed among growing media in both seasons. Application of mineral NPK fertilizer for plants grown in sand + peat (1:2) had significantly the highest value of chlorophyll (a), while the control plants grown in sand + peat $(2: 1)$ resulted in significantly the least values in both seasons.

\subsubsection{Chlorophyll (b)}

The promotion of chlorophyll (b) was associated with using mineral NPK fertilizer, vermicompost tea, spent mushroom compost tea and filter mud tea in descending order, whereas the least value was significantly occurred by control in both seasons. No significant differences were observed among growing media in both seasons. Application of mineral NPK fertilizer for plants grown in sand+ peat (1:2) resulted in significantly the highest value of chlorophyll (b). On the other hand, the control plants grown in sand + peat (2:1) had significantly the least values in both seasons.

\subsubsection{Total chlorophyll $(a+b)$}

The highest significant value of leaf content of total chlorophyll was attained by mineral NPK fertilizer, vermicompost tea followed by spent mushroom compost tea then filter mud tea. Control plants exhibited significantly the least value in both seasons. Concerning the type of growing media, data showed that no significant differences were observed among them in both seasons. Application of mineral NPK fertilizer for plants grown in sand: peat mixture (1:2) had significantly the highest value of total 
Table (3): Effects of organic fertilizers and growing media on flowering parameters of Gardenia jasminoides during 2017 and 2018 seasons.

\begin{tabular}{|c|c|c|c|c|c|c|c|c|}
\hline \multirow{4}{*}{$\begin{array}{c}\text { Organic } \\
\text { fertilizers (A) }\end{array}$} & \multicolumn{8}{|c|}{ Growing media- Sand: Peat moss (B) } \\
\hline & $1: 1$ & $1: 2$ & $2: 1$ & $\begin{array}{l}\text { Means } \\
\text { (B) }\end{array}$ & 1:1 & $1: 2$ & $2: 1$ & Means (A) \\
\hline & \multicolumn{4}{|c|}{ First season } & \multicolumn{4}{|c|}{ Second season } \\
\hline & \multicolumn{8}{|c|}{ Flowering date (Day) } \\
\hline Control & 201 & 199 & 200 & 200 & 205 & 203 & 204 & 204 \\
\hline NPK & 177 & 176 & 179 & 177 & 179 & 177 & 179 & 178 \\
\hline Filter mud tea & 185 & 185 & 186 & 185 & 186 & 184 & 187 & 186 \\
\hline $\begin{array}{l}\text { Spent mushroom } \\
\text { compost tea }\end{array}$ & 185 & 184 & 185 & 185 & 187 & 186 & 188 & 187 \\
\hline Vermicompost tea & 179 & 178 & 180 & 179 & 179 & 177 & 179 & 178 \\
\hline Means (B) & 185 & 184 & 186 & & 187 & 185 & 187 & \\
\hline \multirow[t]{2}{*}{ LSD 5\% } & $A=5$ & $\mathrm{~B}=4$ & $\mathrm{AB}=9$ & & $A=4$ & $\mathrm{~B}=3$ & $\mathrm{AB}=6$ & \\
\hline & \multicolumn{8}{|c|}{ Flowering plants $(\%)$} \\
\hline Control & 66.6 & 77.7 & 66.6 & 70.3 & 64.8 & 75.6 & 64.8 & 68.4 \\
\hline NPK & 66.6 & 66.6 & 55.5 & 62.9 & 64.8 & 64.8 & 54.0 & 61.2 \\
\hline Filter mud tea & 77.7 & 88.9 & 66.6 & 77.7 & 75.6 & 86.5 & 64.8 & 75.6 \\
\hline $\begin{array}{l}\text { Spent mushroom } \\
\text { compost tea }\end{array}$ & 88.9 & 100.0 & 66.6 & 85.2 & 86.5 & 97.3 & 64.8 & 82.9 \\
\hline Vermicompost tea & 88.9 & 100.0 & 77.7 & 88.9 & 86.5 & 97.3 & 75.6 & 86.5 \\
\hline Means (B) & 77.7 & 86.6 & 66.6 & & 75.6 & 84.3 & 64.8 & \\
\hline \multirow[t]{2}{*}{ LSD 5\% } & $\mathrm{A}=23.6$ & $\mathrm{~B}=18.3$ & $\mathrm{AB}=40.9$ & & $\mathrm{~A}=20.7$ & $\mathrm{~B}=16.1$ & $\mathrm{AB}=35.9$ & \\
\hline & \multicolumn{8}{|c|}{ No. of flowers/plant } \\
\hline Control & 3.77 & 5.53 & 2.99 & 4.10 & 4.31 & 6.34 & 3.42 & 4.69 \\
\hline NPK & 4.13 & 4.97 & 2.97 & 4.02 & 4.73 & 5.69 & 3.40 & 4.61 \\
\hline Filter mud tea & 4.67 & 5.27 & 3.17 & 4.37 & 5.34 & 6.03 & 3.63 & 5.00 \\
\hline $\begin{array}{l}\text { Spent mushroom } \\
\text { compost tea }\end{array}$ & 5.00 & 6.00 & 3.00 & 4.67 & 5.73 & 6.87 & 3.44 & 5.34 \\
\hline Vermicompost tea & 5.33 & 6.33 & 4.07 & 5.24 & 6.11 & 7.25 & 4.66 & 6.00 \\
\hline Means (B) & 4.58 & 5.62 & 3.24 & & 5.24 & 6.43 & 3.71 & \\
\hline \multirow[t]{2}{*}{ LSD 5\% } & $\mathrm{A}=1.19$ & $\mathrm{~B}=0.92$ & $\mathrm{AB}=2.06$ & & $\mathrm{~A}=1.36$ & $\mathrm{~B}=1.06$ & $\mathrm{AB}=2.36$ & \\
\hline & \multicolumn{8}{|c|}{ Average flower fresh weight $(\mathrm{g})$} \\
\hline Control & 1.87 & 1.60 & 1.50 & 1.66 & 2.14 & 1.83 & 1.72 & 1.90 \\
\hline NPK & 1.67 & 2.53 & 2.10 & 2.10 & 1.91 & 2.90 & 2.40 & 2.40 \\
\hline Filter mud tea & 2.50 & 2.90 & 2.33 & 2.58 & 2.86 & 3.32 & 2.67 & 2.95 \\
\hline $\begin{array}{l}\text { Spent mushroom } \\
\text { compost tea }\end{array}$ & 2.70 & 3.03 & 2.43 & 2.72 & 3.09 & 3.47 & 2.79 & 3.12 \\
\hline Vermicompost tea & 3.83 & 3.23 & 2.50 & 2.83 & 3.24 & 3.70 & 2.86 & 3.27 \\
\hline Means (B) & 2.31 & 2.66 & 2.17 & & 2.65 & 3.05 & 2.49 & \\
\hline LSD 5\% & $\mathrm{A}=0.51$ & $\mathrm{~B}=0.39$ & $\mathrm{AB}=0.88$ & & $\mathrm{~A}=0.58$ & $\mathrm{~B}=0.45$ & $\mathrm{AB}=1.00$ & \\
\hline
\end{tabular}

chlorophyll, while control plants grown in sand + peat $(2: 1)$ resulted in significantly the least value in both seasons. These results are in accordance with those obtained by Abd El Gayed and Attia (2018) on Celosia argentea who found that the maximum beneficial effect on leaf content of total chlorophyll was occurred in plants received NPK fertilizer (20:20:20) compared to untreated plants.

\subsection{Leaf contents of mineral elements}

\subsubsection{Nitrogen (\% D.W)}

Table (5) shows that organic fertilization of gardenia with vericompost tea or filter mud tea resulted in the highest significant $\mathrm{N}^{-}$content, while the control plants recorded the lowest. Also, plants grown on a mixture of 2 sand +1 peat contained higher significant nitrogen content than the two other media.

Plants grown on sand + peat moss $(1: 2)$ and treated with vericompost tea recorded the greatest value of $\mathrm{N}^{-}$uptake. Whereas, the lowest significant levels were measured by the control plants grown in the mixture 2 sand: 1 peat.

3.5.2. Phosphorus (\% D.W)

Growing media have no significant influence on phosphorus uptake (Table 5), while organic fertilization significantly affected it as the three organic fertilizers under investigation 
Table (4): Effects of organic fertilizers and growing media on leaf contents of pigments of Gardenia jasminoides during 2017 and 2018 seasons

\begin{tabular}{|c|c|c|c|c|c|c|c|c|}
\hline \multirow{4}{*}{$\begin{array}{c}\text { Organic } \\
\text { fertilizers (A) }\end{array}$} & \multicolumn{8}{|c|}{ Growing media- Sand: Peat moss (v/v) (B) } \\
\hline & 1:1 & $1: 2$ & $2: 1$ & $\begin{array}{l}\text { Means } \\
\text { (B) }\end{array}$ & $1: 1$ & $1: 2$ & $2: 1$ & $\begin{array}{l}\text { Means } \\
\text { (A) }\end{array}$ \\
\hline & \multicolumn{4}{|c|}{ First season } & \multicolumn{4}{|c|}{ Second season } \\
\hline & \multicolumn{8}{|c|}{ Chlorophyll (A) (mg/g f.w) } \\
\hline Control & 0.87 & 0.72 & 0.68 & 0.76 & 0.99 & 0.83 & 0.78 & 0.87 \\
\hline NPK & 2.51 & 2.64 & 2.41 & 2.52 & 2.88 & 3.03 & 2.76 & 2.89 \\
\hline Filter mud tea & 1.93 & 2.11 & 2.11 & 2.05 & 2.21 & 2.42 & 2.41 & 2.35 \\
\hline $\begin{array}{l}\text { Spent mushroom } \\
\text { compost tea }\end{array}$ & 2.03 & 2.31 & 2.25 & 2.20 & 2.33 & 2.65 & 2.58 & 2.52 \\
\hline Vermicompost tea & 2.44 & 2.46 & 2.52 & 2.47 & 2.79 & 2.82 & 2.89 & 2.83 \\
\hline Means (B) & 1.96 & 2.05 & 1.99 & & 2.24 & 2.35 & 2.28 & \\
\hline \multirow[t]{2}{*}{ LSD 5\% } & $\mathrm{A}=0.37$ & $\mathrm{~B}=\mathrm{N} . \mathrm{S}$. & $\mathrm{AB}=0.64$ & & $\mathrm{~A}=0.42$ & $\mathrm{~B}=\mathrm{N} . \mathrm{S}$. & $\mathrm{AB}=0.73$ & \\
\hline & \multicolumn{8}{|c|}{ Chlorophyll (B) (mg/g f.w) } \\
\hline Control & 0.11 & 0.12 & 0.09 & 0.11 & 0.12 & 0.14 & 0.11 & 0.12 \\
\hline NPK & 0.19 & 0.24 & 0.20 & 0.21 & 0.22 & 0.28 & 0.23 & 0.22 \\
\hline Filter mud tea & 0.13 & 0.11 & 0.15 & 0.13 & 0.15 & 0.12 & 0.17 & 0.15 \\
\hline $\begin{array}{l}\text { Spent mushroom } \\
\text { compost tea }\end{array}$ & 0.22 & 0.19 & 0.11 & 0.18 & 0.26 & 0.22 & 0.13 & 0.26 \\
\hline Vermicompost tea & 0.19 & 0.22 & 0.16 & 0.19 & 0.22 & 0.25 & 0.18 & 0.22 \\
\hline Means (B) & 0.17 & 0.18 & 0.14 & & 0.12 & 0.14 & 0.11 & 0.12 \\
\hline \multirow[t]{2}{*}{ LSD 5\% } & $\mathrm{A}=0.05$ & $\mathrm{~B}=\mathrm{N} . \mathrm{S}$. & $\mathrm{AB}=0.08$ & & $\mathrm{~A}=0.03$ & $\mathrm{~B}=\mathrm{N} . \mathrm{S}$. & $\mathrm{AB}=0.05$ & \\
\hline & \multicolumn{8}{|c|}{ Total chlorophyll (A+B) (mg/g f.w) } \\
\hline Control & 0.98 & 0.85 & 0.77 & 0.86 & 1.12 & 0.97 & 0.88 & 0.99 \\
\hline NPK & 2.71 & 2.88 & 2.61 & 2.73 & 3.10 & 3.30 & 2.99 & 3.13 \\
\hline Filter mud tea & 2.06 & 2.22 & 2.26 & 2.18 & 2.36 & 2.54 & 2.58 & 2.50 \\
\hline $\begin{array}{l}\text { Spent mushroom } \\
\text { compost tea }\end{array}$ & 2.26 & 2.50 & 2.36 & 2.37 & 2.58 & 2.86 & 2.71 & 2.72 \\
\hline Vermicompost tea & 2.63 & 2.68 & 2.68 & 2.66 & 3.01 & 3.06 & 3.06 & 3.05 \\
\hline Means (B) & 2.13 & 2.23 & 2.14 & & 2.43 & 2.55 & 2.44 & \\
\hline LSD 5\% & $A=0.25$ & $\mathrm{~B}=\mathrm{N} . \mathrm{S}$. & $\mathrm{AB}=0.43$ & & $\mathrm{~A}=0.28$ & $\mathrm{~B}=$ N.S. & $\mathrm{AB}=0.49$ & \\
\hline
\end{tabular}

significantly improved phosphorus content compared with the control and NPK fertilizer. Gardenia plants grown in 1 sand: 2 peat moss contained the highest phosphorus level, while those grown in 2 sand: 1 peat or the control plants recorded the lowest significant content.

\subsubsection{Potassium (\% D.W)}

As shown in Table (5), $\mathrm{K}^{+}$content significantly untreated plants was affected by application of organic fertilizers and different growing mixture either alone or in combination compared to the control in both seasons. The highest significant leaf content of $\mathrm{K}^{+}$was detected in plants fertilized with vericompost tea, while the lowest significant one was measured for the control plants. Gardenia grown on a medium of sand + peat $(1: 2)$ contained the highest significant potassium content.

Gardenia plants grown in mixture of 1 sand: 2 peat and revived vericompost tea contained the highest significant concentration of potassium.
These findings may be attributed to the ability of compost tea to improve the absorption and translocation of $\mathrm{N}, \mathrm{P}$ and $\mathrm{K}$ by leaves tissues. As previously mentioned, the use of tea compost increased plant macronutrient contents, and this is related to a positive effect on increasing the root surface area per unit of soil volume, water use efficiency and photosynthetic activity, directly affect physiological processes. Compost tea sources increased N, P and $\mathrm{K}$ uptake (Siddiqui et al., 2011). The same trend was observed by Fouda and Ali (2016) who reported that the application of tea compost increased the $\mathrm{N}$ uptake of radish leaf by about $30.1 \%$ over the control, compost tea also increased the $\mathrm{P}$ and $\mathrm{K}$ uptake by 12.6 and $51.5 \%$, respectively.

\subsection{Soil content of mineral elements}

Data in Table (6) show the effects of growing media and organic fertilizers on soil contents of $\mathrm{N}, \mathrm{P}$ and $\mathrm{K}$ in the rhizosphere zone of gardenia plants. 
Table(5): Effects of organic fertilizers and growing media on leaf contents of $\mathbf{N}, \mathbf{P}$ and $\mathbf{K}$ of Gardenia jasminoides during 2017 and 2018 seasons

\begin{tabular}{|c|c|c|c|c|c|c|c|c|}
\hline \multirow{4}{*}{$\begin{array}{l}\text { Organic fertilizers } \\
\text { (A) }\end{array}$} & \multicolumn{8}{|c|}{ Growing media- Sand: Peat moss (v/v) (B) } \\
\hline & $1: 1$ & $1: 2$ & $2: 1$ & $\begin{array}{l}\text { Means } \\
\text { (B) }\end{array}$ & 1:1 & $1: 2$ & $2: 1$ & $\begin{array}{l}\text { Means } \\
\text { (A) }\end{array}$ \\
\hline & \multicolumn{4}{|c|}{ First season } & \multicolumn{4}{|c|}{ Second season } \\
\hline & \multicolumn{8}{|c|}{ Nitrogen (\% d.w) } \\
\hline Control & 1.024 & 1.126 & 0.811 & 0.987 & 1.028 & 0.912 & 0.921 & 0.954 \\
\hline NPK & 1.061 & 1.529 & 0.833 & 1.141 & 1.088 & 1.181 & 1.223 & 1.164 \\
\hline Filter mud tea & 1.262 & 1.690 & 1.215 & 1.389 & 1.281 & 1.757 & 1.302 & 1.447 \\
\hline $\begin{array}{l}\text { Spent mushroom } \\
\text { compost tea }\end{array}$ & 1.065 & 1.197 & 1.008 & 1.090 & 1.025 & 1.131 & 1.011 & 1.056 \\
\hline Vermicompost tea & 1.452 & 1.901 & 1.256 & 1.536 & 1.432 & 1.877 & 1.551 & 1.620 \\
\hline Means (B) & 1.173 & 1.489 & 1.025 & & 1.171 & 1.372 & 1.202 & \\
\hline \multirow[t]{2}{*}{ LSD 5\% } & $\mathrm{A}=0.053$ & $\mathrm{~B}=0.041$ & $\mathrm{~A} \times \mathrm{B}=0.091$ & & $\mathrm{~A}=0.063$ & $\mathrm{~B}=0.042$ & $\mathrm{~A} \times \mathrm{B}=0.098$ & \\
\hline & \multicolumn{8}{|c|}{ Phosphorus (\% d.w) } \\
\hline Control & 0.112 & 0.116 & 0.065 & 0.098 & 0.111 & 0.117 & 0.068 & 0.099 \\
\hline NPK & 0.113 & 0.178 & 0.111 & 0.134 & 0.121 & 0.166 & 0.108 & 0.132 \\
\hline Filter mud tea & 0.166 & 0.207 & 0.163 & 0.179 & 0.182 & 0.212 & 0.162 & 0.185 \\
\hline $\begin{array}{l}\text { Spent mushroom } \\
\text { compost tea }\end{array}$ & 0.159 & 0.187 & 0.160 & 0.169 & 0.177 & 0.191 & 0.161 & 0.176 \\
\hline Vermicompost tea & 0.217 & 0.244 & 0.216 & 0.226 & 0.219 & 0.249 & 0.211 & 0.226 \\
\hline Means (B) & 0.153 & 0.186 & 0.143 & & 0.162 & 0.187 & 0.142 & \\
\hline \multirow[t]{2}{*}{ LSD 5\% } & \multicolumn{2}{|c|}{$\mathrm{A}=0.055$} & \multicolumn{2}{|c|}{\begin{tabular}{l|l}
$=$ & $\mathrm{A} \times \mathrm{B}=0.097$ \\
$\mathrm{~S}$. &
\end{tabular}} & \multicolumn{2}{|c|}{$A=0.0501$} & \multicolumn{2}{|c|}{$\mathrm{A} \times \mathrm{B}=0.091$} \\
\hline & \multicolumn{8}{|c|}{ Potassium (\% d.w) } \\
\hline Control & 0.668 & 0.676 & 0.629 & 0.658 & 0.655 & 0.681 & 0.608 & 0.648 \\
\hline NPK & 0.725 & 0.973 & 0.634 & 0.777 & 0.698 & 0.992 & 0.655 & 0.782 \\
\hline Filter mud tea & 1.144 & 1.181 & 1.008 & 1.111 & 1.151 & 1.210 & 1.013 & 1.125 \\
\hline $\begin{array}{l}\text { Spent mushroom } \\
\text { compost tea }\end{array}$ & 1.007 & 1.098 & 0.848 & 0.984 & 1.009 & 1.091 & 0.865 & 0.988 \\
\hline Vermicompost tea & 1.221 & 1.806 & 1.170 & 1.399 & 1.201 & 1.758 & 1.188 & 1.382 \\
\hline Means (B) & 0.953 & 1.147 & 0.858 & & 0.943 & 1.146 & 0.866 & \\
\hline LSD 5\% & $\mathrm{A}=0.068$ & $\mathrm{~B}=$ & 53 & 0.119 & $\mathrm{~A}=0.06$ & & .047 & $=0.107$ \\
\hline
\end{tabular}

\subsubsection{Nitrogen (\% D.W)}

The mixture of sand and peat at ratio of 1: 2 $(\mathrm{v} / \mathrm{v})$ resulted in the highest nitrogen contents. Vermicompost tea did not significantly differ from filter mud tea in their effect on $\mathrm{N}$-content. The lowest significant value of $\mathrm{N} \%$ was recorded for the control plants without fertilization. Vermicompost tea applied to the mixture of 1 sand: 2 peat resulted in the highest significant soil nitrogen content.

\subsubsection{Phosphorus (\% D.W)}

Soil $\mathrm{P}^{-}$content took the same trend of soil $\mathrm{N}^{-}$ content. Fertilization with vermicompost tea recorded the highest significant soil content of phosphorus, and 1 sand: 2 peat resulted in the highest phosphorus contents. The highest significant soil phosphorus content was detected for 1 sand: 2 peat recived vermicompost tea.

\subsubsection{Potassium (\% D.W)}

Both organic fertilization and growing media have significant effect on soil potassium content. The highest significant value of potassium content in the soil was detected for $1: 2$ sand + peat amended with vermicompost tea fertilization.

Fouda and Ali (2016) mentioned that there were greater $\mathrm{N}, \mathrm{P}$ and $\mathrm{K}$ in soil receiving compost of compost tea, and the contents increased with increasing compost tea ratios. Siddiqui et al. (2011) found that application of compost tea increased $\mathrm{N}, \mathrm{P}$ and $\mathrm{K}$ soil content compared with inorganic fertilizer alone, and the increase depended on compost tea ratios 
Table (6): Effects of organic fertilizers and growing media on soil contents of $\mathbf{N}, \mathrm{P}$ and $\mathrm{K}$ of Gardenia jasminoides during 2017 and 2018 seasons.

\begin{tabular}{|c|c|c|c|c|c|c|c|c|}
\hline \multirow{4}{*}{$\begin{array}{c}\text { Organic } \\
\text { fertilizers (A) }\end{array}$} & \multicolumn{8}{|c|}{ Growing media- Sand: Peat moss (v/v) (B) } \\
\hline & $1: 1$ & $1: 2$ & $2: 1$ & Means (B) & 1:1 & $1: 2$ & $2: 1$ & Means (A) \\
\hline & \multicolumn{4}{|c|}{ First season } & \multicolumn{4}{|c|}{ Second season } \\
\hline & \multicolumn{8}{|c|}{ Nitrogen $(\%)$} \\
\hline Control & 0.58 & 0.78 & 0.39 & 0.58 & 0.51 & 0.73 & 0.40 & 0.55 \\
\hline NPK & 1.08 & 1.12 & 1.08 & 1.09 & 0.91 & 1.07 & 1.04 & 1.01 \\
\hline Filter mud tea & 1.18 & 1.29 & 1.11 & 1.19 & 1.15 & 1.26 & 1.04 & 1.15 \\
\hline $\begin{array}{l}\text { Spent mushroom } \\
\text { compost tea }\end{array}$ & 0.90 & 0.93 & 0.89 & 0.91 & 0.90 & 1.04 & 0.85 & 0.93 \\
\hline Vermicompost tea & 1.18 & 1.40 & 1.14 & 1.24 & 1.34 & 1.35 & 1.05 & 1.25 \\
\hline Means (B) & 0.98 & 1.10 & 0.92 & & 0.96 & 1.09 & 0.88 & \\
\hline \multirow[t]{2}{*}{ LSD 5\% } & $\mathrm{A}=0.11$ & \multicolumn{2}{|c|}{$\mathrm{B}=0.08$} & $\mathrm{~A} \times \mathrm{B}=0.19$ & $\mathrm{~A}=0.13$ & \multicolumn{2}{|c|}{$\mathrm{B}=0.10$} & $\mathrm{~A} \times \mathrm{B}=0.23$ \\
\hline & \multicolumn{8}{|c|}{ Phosphorus (\%) } \\
\hline Control & 0.003 & 0.004 & 0.001 & 0.003 & 0.004 & 0.004 & 0.002 & 0.003 \\
\hline NPK & 0.010 & 0.014 & 0.007 & 0.010 & 0.013 & 0.024 & 0.008 & 0.015 \\
\hline Filter mud tea & 0.035 & 0.115 & 0.016 & 0.055 & 0.018 & 0.138 & 0.014 & 0.057 \\
\hline $\begin{array}{l}\text { Spent mushroom } \\
\text { compost tea }\end{array}$ & 0.015 & 0.022 & 0.007 & 0.015 & 0.018 & 0.034 & 0.009 & 0.020 \\
\hline Vermicompost tea & 0.141 & 0.166 & 0.099 & 0.135 & 0.107 & 0.152 & 0.102 & 0.120 \\
\hline Means (B) & 0.041 & 0.064 & 0.026 & & 0.032 & 0.070 & 0.027 & \\
\hline \multirow[t]{2}{*}{ LSD 5\% } & \multicolumn{3}{|c|}{$\mathrm{A}=0.030$} & $\mathrm{~A} \times \mathrm{B}=0.053$ & \multicolumn{2}{|c|}{$\mathrm{A}=0.031$} & 0.028 & $\mathrm{~A} \times \mathrm{B}=0.059$ \\
\hline & \multicolumn{8}{|c|}{ Potassium (\%) } \\
\hline Control & 0.032 & 0.033 & 0.013 & 0.026 & 0.030 & 0.056 & 0.013 & 0.033 \\
\hline NPK & 0.032 & 0.044 & 0.021 & 0.032 & 0.031 & 0.061 & 0.022 & 0.038 \\
\hline Filter mud tea & 0.045 & 0.141 & 0.033 & 0.073 & 0.044 & 0.132 & 0.031 & 0.069 \\
\hline $\begin{array}{l}\text { Spent mushroom } \\
\text { compost tea }\end{array}$ & 0.042 & 0.064 & 0.021 & 0.042 & 0.035 & 0.075 & 0.025 & 0.045 \\
\hline Vermicompost tea & 0.071 & 0.173 & 0.033 & 0.092 & 0.048 & 0.166 & 0.035 & 0.083 \\
\hline Means (B) & 0.044 & 0.091 & 0.024 & & 0.038 & 0.098 & 0.025 & \\
\hline LSD 5\% & \multicolumn{2}{|c|}{$A=0.04$} & .031 & $\mathrm{~A} \times \mathrm{B}=0.075$ & $\mathrm{~A}=0.0$ & & $=0.029$ & $\mathrm{~A} \times \mathrm{B}=0.077$ \\
\hline
\end{tabular}

\subsection{Biological activities in rhizospher soil of gardenia plants}

Both growing media and organic fertilization significantly influenced microbiological counts and dehydrogenase activity of the soil (Table 7).

\subsubsection{Bacterial counts}

The highest counts were found in vermicompost tea fertilized soil, being $58.16 \mathrm{x}$ $10^{5}$ and $56.30 \times 10^{5} \mathrm{CFUg}^{-1}$ during the two seasons respectively. The growing medium consists of 1 sand: 2 peat recorded the highest bacterial count $\left(55.26\right.$ and $53.08 \times 10^{5} \mathrm{cfu} / \mathrm{g}$ for the two seasons, respectively).

Applying vermicompost tea to 1 sand: 2 peat growing medium resulted in numbers of bacteria representing 111.20 and $110.85 \times 10^{5} \mathrm{cfu} / \mathrm{g}$ soil, respectively.

\subsubsection{Fungal counts}

The highest fungal number was detected in the soil fertilized with vermicompost tea, being
90.93 and $87.59 \times 10^{3} \mathrm{cfu} / \mathrm{g}$ soil, in the first and second seasons, respectively. Using a medium consisting of sand + peat at ratio of $1: 2$ supported fungal growth with counts 49.79 and $47.10 \times 10^{3} \mathrm{cfu} / \mathrm{g}$ for the two seasons.

The greatest soil fungal count was detected in rhizosphere soil of gardenia plants grown in 1 sand: 2 peat soil mixture and fertilized with vermicompost tea reaching 102.1 and $98.53 \mathrm{cfu}$ /g during the two seasons respectively.

\subsubsection{Actinomycets counts}

The best treatment achieved the highly counts of actinomycetes in rhizosphere was vermicompost tea that recorded 98.84 and 94.68 x $10^{3} \mathrm{cfu} / \mathrm{g}$ during two seasons, respectively. Using media consisting of sand + peat at ratio of 1:2 favored for actinomycetes to reach the maximum counts $\left(70.86\right.$ and $68.42 \times 10^{3} \mathrm{cfu} / \mathrm{g}$, respectively). and. The highest counts were detected for the treatment of vermicompost tea 
Table (7): Effects of organic fertilizers and growing media on microbial counts in rhizospher of Gardenia jasminoides during 2017 and 2018 seasons.

\begin{tabular}{|c|c|c|c|c|c|c|c|c|}
\hline \multirow{4}{*}{$\begin{array}{c}\text { Organic } \\
\text { fertilizers (A) }\end{array}$} & \multicolumn{8}{|c|}{ Growing media- Sand: Peat moss (v/v) (B) } \\
\hline & 1:1 & $1: 2$ & $2: 1$ & $\begin{array}{l}\text { Means } \\
\text { (B) }\end{array}$ & 1:1 & $1: 2$ & $2: 1$ & $\begin{array}{l}\text { Means } \\
\text { (A) }\end{array}$ \\
\hline & \multicolumn{4}{|c|}{ First season } & \multicolumn{4}{|c|}{ Second season } \\
\hline & \multicolumn{8}{|c|}{ Bacterial count $\left(10^{5} \mathrm{cfu} / \mathrm{g}\right)$} \\
\hline Control & 11.60 & 25.03 & 10.60 & 15.74 & 12.04 & 25.88 & 9.25 & 15.72 \\
\hline NPK & 19.07 & 43.83 & 12.77 & 25.22 & 20.22 & 32.58 & 13.99 & 22.26 \\
\hline Filter mud tea & 30.30 & 50.73 & 23.73 & 34.92 & 26.05 & 53.55 & 25.22 & 34.94 \\
\hline $\begin{array}{l}\text { Spent mushroom } \\
\text { compost tea }\end{array}$ & 27.30 & 44.53 & 16.53 & 29.45 & 25.62 & 42.55 & 17.32 & 28.50 \\
\hline Vermicompost tea & 34.97 & 112.20 & 27.30 & 58.16 & 29.69 & 110.85 & 28.35 & 56.30 \\
\hline Means (B) & 24.65 & 55.26 & 18.19 & & 22.72 & 53.08 & 18.83 & \\
\hline \multirow[t]{2}{*}{ LSD 5\% } & $\mathrm{A}=1.44$ & $\mathrm{~B}=1.12$ & $\mathrm{~A} \times \mathrm{B}=2.49$ & & $\mathrm{~A}=1.39$ & $\mathrm{~B}=1.13$ & $\mathrm{~A} \times \mathrm{B}=2.55$ & \\
\hline & \multicolumn{8}{|c|}{ Fungal count $\left(10^{3} \mathrm{cfu} / \mathrm{g}\right)$} \\
\hline Control & 18.62 & 25.78 & 11.2 & 18.53 & 19.34 & 24.89 & 10.33 & 18.19 \\
\hline NPK & 20.05 & 32.24 & 11.98 & 21.42 & 21.11 & 29.55 & 10.88 & 20.51 \\
\hline Filter mud tea & 32.73 & 56.18 & 19.2 & 36.04 & 31.55 & 52.18 & 20.11 & 34.61 \\
\hline $\begin{array}{l}\text { Spent mushroom } \\
\text { compost tea }\end{array}$ & 22.38 & 32.64 & 14.52 & 23.18 & 22.09 & 30.36 & 15.25 & 22.57 \\
\hline Vermicompost tea & 98.22 & 102.1 & 72.47 & 90.93 & 94.88 & 98.53 & 69.35 & 87.59 \\
\hline Means (B) & 38.40 & 49.79 & 25.87 & & 37.79 & 47.10 & 25.18 & \\
\hline \multirow[t]{2}{*}{ LSD 5\% } & $\mathrm{A}=1.81$ & $\mathrm{~B}=1.40$ & $\mathrm{~A} \times \mathrm{B}=3.14$ & & $\mathrm{~A}=1.91$ & $\mathrm{~B}=1.42$ & $\mathrm{~A} \times \mathrm{B}=3.21$ & \\
\hline & \multicolumn{8}{|c|}{ Actinomycetes $\left(10^{3} \mathrm{cfu} / \mathrm{g}\right)$} \\
\hline Control & 30.62 & 35.39 & 15.83 & 27.28 & 31.25 & 34.51 & 17.33 & 27.70 \\
\hline NPK & 33.17 & 50.73 & 22.62 & 35.51 & 31.25 & 48.61 & 25.15 & 35.00 \\
\hline Filter mud tea & 48.83 & 90.73 & 43.25 & 60.94 & 49.33 & 88.31 & 45.25 & 60.96 \\
\hline $\begin{array}{l}\text { Spent mushroom } \\
\text { compost tea }\end{array}$ & 33.32 & 64.27 & 25.73 & 41.11 & 32.55 & 62.15 & 28.21 & 40.97 \\
\hline Vermicompost tea & 100.1 & 113.20 & 83.21 & 98.84 & 95.17 & 108.51 & 80.35 & 94.68 \\
\hline Means (B) & 49.21 & 70.86 & 38.13 & & 47.91 & 68.42 & 39.26 & \\
\hline LSD 5\% & $\mathrm{A}=3.11$ & $\mathrm{~B}=2.41$ & $\mathrm{~A} \times \mathrm{B}=5.39$ & & $\mathrm{~A}=3.22$ & $\mathrm{~B}=2.51$ & $\mathrm{~A} \times \mathrm{B}=5.45$ & \\
\hline
\end{tabular}

and 1sand: 2 peatmoss growing medium (113.20 and $108.51 \times 10^{3} \mathrm{cfu} / \mathrm{g}$ during the two seasons, respectively).

Microbial communities are usually considered as important indicators of soil fertility because of their association with plant nutrition (Lei et al., 2016). Compost tea contains a high population of microbes, which may enhance growth and yield of crops. Besides, these microbes produce plant growth hormones and chemical compounds (siderophores, tannins and phenols) which are antagonistic to various soil pathogens. In addition, other microbes may benefit plants through mechanisms such as $\mathrm{N}^{-}$ fixation and phosphate solubilization. The use of compost extract is also claimed to increase soil carbon levels, improve soil structure, nutrient cycling, and water holding capacity and suppress plant diseases. So, compost tea applied as foliar spray with plowing rice straw on barely plants gave the highest values of all soil biological activity parameters. Where, total bacteria count $135 \times 10^{7}$ and $176 \times 10^{7} \mathrm{cfu} \mathrm{g}^{-1}$ dry soil while, total fungi $1.8 \times 10^{3}$ and $28 \times 10^{3}$ cfu g-1 dry soil and total actinomycetes were $91 \times 10^{3}$ and 192 $\mathrm{x} 10^{3} \mathrm{cfu} \mathrm{g}^{-1}$ dry at 50 and 90 days from sowing, respectively (Khalil et al., 2014). Also, compost tea application had different influences on soil microbial population. In this concern, Taha et al. (2016) reported that population of bacteria, and fungi were significantly affected by the compost tea treatments, whereas actinomycetes were not significantly affected by these treatments. Also, Heather et al. (2006) stated that bacterial counts were higher in the soil treated with compost and compost tea; this can be explained by the increased nutrition supplement due to the compost and compost tea. On the other hand, 
Table (8): Effect of organic fertilizers and growing media on dehydrogenase enzyme activities in rhizospher of Gardenia jasminoides during 2017 and 2018 seasons.

\begin{tabular}{|c|c|c|c|c|c|c|c|c|}
\hline \multirow{3}{*}{$\begin{array}{l}\text { Organic fertilizers } \\
\text { (A) }\end{array}$} & \multicolumn{8}{|c|}{ Growing media- Sand: Peat moss (v/v) (B) } \\
\hline & 1:1 & $1: 2$ & 2:1 & $\begin{array}{l}\text { Means } \\
\text { (B) }\end{array}$ & 1:1 & $1: 2$ & 2:1 & $\begin{array}{l}\text { Means } \\
\text { (A) }\end{array}$ \\
\hline & \multicolumn{4}{|c|}{ First season } & \multicolumn{4}{|c|}{ Second season } \\
\hline Control & 4.07 & 6.08 & 3.80 & 4.65 & 4.11 & 5.89 & 3.58 & 4.53 \\
\hline NPK & 7.27 & 11.59 & 6.45 & 8.44 & 7.33 & 13.1 & 6.81 & 9.08 \\
\hline Filter mud tea & 13.19 & 19.55 & 12.68 & 15.14 & 13.25 & 20.25 & 12.35 & 15.28 \\
\hline $\begin{array}{l}\text { Spent mushroom } \\
\text { compost tea }\end{array}$ & 12.99 & 13.28 & 12.26 & 12.84 & 13.19 & 13.69 & 11.92 & 12.93 \\
\hline Vermicompost tea & 20.52 & 21.18 & 16.13 & 19.28 & 21.25 & 22.55 & 16.01 & 19.94 \\
\hline Means (B) & 11.61 & 14.34 & 10.26 & & 11.83 & 15.10 & 10.13 & \\
\hline LSD 5\% & $\mathrm{A}=0.22$ & $\mathrm{~B}=0$ & & $\times \mathrm{B}=0.4$ & $\mathrm{~A}=0.24$ & & & $\mathrm{~A} \times \mathrm{B}=0.9$ \\
\hline
\end{tabular}

Hegazy et al. (2013) reported that the total fungal counts in soil were decreased by compost tea treatment.

\subsubsection{Dehydrogenase enzymes activity}

Highly significant values of dehydrogenase activities were detected as a result of vermicompost tea application recording 21.18 and $22.55 \mu \mathrm{g} \mathrm{TPF} / \mathrm{g}$ soil during two seasons, respectively. Also, the growing media had a significant influence on the enzyme activity where the highest activities were detected for 1 sand: 2 peat (14.34 and $15.10 \mu \mathrm{g}$ TPF/g soil, respectively). In respect to the interaction effect, the highest significant values of dehydrogenase were reported by applying vermicompost tea to growing medium of 1 sand: 2 peat being 21.18 and $22.55 \mu \mathrm{g} \mathrm{TPF} / \mathrm{g}$ soil for the two seasons as shown in Table (8).

Many studies showed that the application of organic fertilizers increases overall enzyme activity. Dehydrogenase enzyme increased from 337.04 to $512.59 \mu \mathrm{g}$ TPF g-1 dry representing increase percentages from 91.89 to $245.68 \mu \mathrm{g} \mathrm{g}^{-1}$ dry soil with combination between compost tea and PGPR treatments at 50 and 90 day respectively (Khalil et al., 2014). Soil dehydrogenase activity reflects the oxidative activity of soil microflora and is consequently used as an indicator of microbial activity (Masciandaro et al., 1994).

\section{Conclusion}

It could be recommended that fertilization vermicompost tea of plants grown in sand + peat $(1: 2 \mathrm{v} / \mathrm{v})$ medium magnified growth traits and increased leaf contents of total chlorophyll and mineral elements which reflect on producing high flowers with a good quality attributes of Gardenia jasminoides plants.

\section{REFERENCES}

Abd El Gayed M. E. and Attia E.A. (2018). Impact of growing media and compound fertilizer rates on growth and flowering of cocks comb (Celosia argentea) plants. J. Plant Prod., Mansoura Univ.,Egypt, 9 (11): $895-900$.

Abdou M. A. (2002). Influence of NPK and micronutrients on growth, flowering and chemical constituents of Borago officinalis, L. plants grown in sandy soil. Proc. Minia $1^{\text {st }}$ Conf. for Agric. \& Env. Sci., 22(2):1659-1672.

Allinson G., Stagnitti F., Salzman S. A., Dover K. J., Venner J. P. and Thwaites L. A. (2000). Behavior of "Organic" and "Synthetic" Fertilizer Nutrients When Applied to Irrigated, Unsaturated Soil, Bull. Environ. Contam. Toxicol., 64: 644650.

Arancon N. Q. and Edwards C. A. (2005). Effects of vermicomposts on plant growth. International Symposium Workshop on Vermi Technologies for Developing Countries (ISWVT 2005), Los Banos, Philippines November, pp. 16-18.

Arancon N. Q., Edwards C. A., Babenko A., Cannon J., Galvis P. and Metzger J.D. (2008). Influences of vermicomposts, produced by earthworms and microorganisms from cattle manure, food waste and paper waste, on the germination, growth and flowering of petunias in the greenhouse. Appl. Soil Ecol. 39:91-99.

Arancon N.Q., Edwards C.A., Atiyeh R.M. and Metzger J.D. (2004). Effects of vermicomposts produced from food waste on greenhouse peppers. Biores. Technol., 93: 139-144. 
Bailey L. H. (1969). Manual of Cultivated Plants, ( $11^{\text {th }}$ printing). The McMillan Co., New York U.S.A. P. 847-860.

Basheer S.N. and Thekkayam S.G. (2012). Effect of growing media and organic nutrition on vegetative growth of anthurium plants (Anthurium andreanum cv. Tropical). Asian J. of Hort., 7(2):354358.

Cabrera R.A.D., Azevedo-Filho A.J.B.V. and Tsai S.M. (2007). Perspective on alternative citrus management: From nursery to field. In: Brown GG, Fragoso C, (eds). Earthworms in Latin America: Biodiversity and ecology. Londrina: Embrapa Soja; P. 525-532.

Casida L.Jr., Klein D. and Santoro T. (1964). Soil dehydrogenase activity. Soil Sci., 98:371-376.

Chauhan H.K. and Singh K. (2013). Effect of tertiary combinations of animal dung with agrowastes on the growth and development of earthworm Eisenia fetida during organic waste management. Int'l J. Recy. Org. Agric. 2:11.

Courtney R. and Mullen G. (2008). Soil quality and barley growth as influenced by the land application of two compost types, Biores. Tech., 99: 2913-2918.

Cros V., Martınez-Sanchez J.J. and Franco J.A. (2007). Good yields of common purslane with a high fatty acid content can be obtained in a peat-based floating system. HortTech., 17, p. 14-20.

Debnath T., Park P.J., Nath N.C.D., Samad N.B., Park H.W. and Lim B.O. (2011). Antioxidant activity of Gardenia jasminoides Ellis fruit extracts. Food Chem.;128:697-703.

Difco Manual (1989). Molecular cloning, a laboratory manual, $2^{\text {nd }}$ ed. Cold Spring Harbor, USA.

Dongardive S.B., Golliwar V.J. and Bhongle S.A. (2007). Effect of organic manure and biofertilizers on growth and flowering of gladiolus cv. White Prosperity. Plant Arch., 7(2):657-658.

Edwards C.A. and Burrows I. (1988). The potential of earthworm composts as plant growth media. In Earthworms in Environmental and Waste Management. C. A., Neuhauser (Ed)., SPB Academic Publ. b.v. The Netherlands. 211-220.

Ercisli S., Sahin U., Esitken A. and Anapali O. (2005). Effects of some growing media on the growth of strawberry cvs. Camarosa and Fern. Acta Agrobot., 58, (1): 185-191.

Fasidi I.O., Kadiri M. and Jonathan S.G. (2008). Adenipekun CO, Kuforiji OO. Cultivation of Tropical Mushrooms. Ibadan: Ibadan University Press.

Fouda S.A. and Ali A.S. (2016). The effects of the conjunctive use of compost tea and inorganic fertilizers on radish (Raphanus sativus) nutrient uptake and soil Microorganisms. Egypt. J. Soil Sci,. 56, (2): 261-280.

Gilam E.F. (1999). Gardenia jasminoides. Dissertation. Gainesville, Florida, USA: University of Florida.

Heather M.D., Alexandra G.S. and Richard P.D. (2006). Compost and manure mediated impacts on soil borne pathogens and soil quality. Soil Sci. Soci. Amer. J., 70: 347358.

Hegazy M.I., Ali A.S. and Entsar E.A. Abbas. (2013). Evaluation of compost and compost extract efficiency as bio-control agents on damping-off disease incidence of fenugreek (Trigonella foenumgreacum). Zagazig J. Agric. Res., 40(2): 239-249.

Hegazi A.Z., Mostafa S.S.M. and Ahmed H.M.I. (2010). Influence of Different Cyanobacterial Application Methods on Growth and Seed Production of Common Bean under Various Levels of Mineral Nitrogen Fertilization. Nat. and Sci., 8(11): 183-194.

Hong I.K., Jeon H. and Lee S.B. (2015). Extraction of natural dye from Gardenia and chromaticity analysis according to chi parameter. J. Ind. Eng. Chem., 24:326332.

Ingham E. (2005). The compost tea brewing manual as printings. Soil Food Web Incorporated, vegan, 3: 31-32.

Jackson M.L. (1967). Soil Chemical Analysis. Printice-Hall Inc. Englewood CliffsU.S.A.

Jamil M. Qasim M. and Zia M.S. (2008). Utilization of press mud as organic amendment to improve physico-chemical characteristics of calcareous soil under two legume crops. J. Chem. Soc. Pak., 30(4):577-583

Jonathan S.G. Lawal M.M. and Oyetunji O.J. (2011). Effect of spent mushroom Compost of Pleurotus pulmonarius on 
Growth Performance of four Nigerian vegetables. Mycobiology, 39(3): 164-169.

Kannangara T., Forge T. and Dang B. (2006). Effects of aeration, molasses, kelp, compost type, and carrot juice on the growth of Escherichia coli in compost teas. Compost Sci. Util., 14:40-47.

Karadeniz A., Topcuoğlu Ş.F. and Ýnan S. (2006). Auxin, gibberellin, cytokinin and abscisic acid production in some bacteria. World J. Microbiol Biotechnol., 22(10):1061-4.

Khalil Heba M. A., El-Akshar Afifi M.M., and Mahmoud Y.I. (2014). Biodynamics for controlling of weeds using bio-organic fertilizers with rice straw and improve productivity barley plants in sandy soil. Inter. J. Acad. Res. Part A, 6 (6): 237-244.

Kist S.G.P., Joseila M., Matos de M.R., Witt S.C., Luiz M.E., Bemfica S.R. and Dias O.F.B. (2019). The vermicompost anticipates flowering and increases tomato productivity. Agrociencia Uruguay 23(1):1-7.

Krucker M., Hummel R.L. and Cogger C. (2010). Chrysanthemum production in composted and noncomposted organic waste substrates fertilized with nitrogen at two rates using surface and sub irrigation. HortSci., 45 (11): 1695-1701.

Kuratsune H., Umigai N., Takeno R., Kajimoto Y., and Nakano T. (2010). Effect of crocetin from Gardenia jasminoides Ellis on sleep: a pilot study. Phytomedi.,17: 840-853.

Lei W., Fang Y., Jun Y., Waseem R., Qiwei H. and Qirong S. (2016). Long-term application of bioorganic fertilizers improved soil biochemical properties and microbial communities of an apple orchard soil. Front. Microbiol., 7: 1-12.

Lim H., Park K.R., Lee D.U., Kim Y.S. and Kim H.P. (2008). Effects of the constituents of Gardenia Fructus on prostaglandin and NO reduction. Biomol. Ther., 16:82-86.

Masciandaro G., Ceccanti B. and Garcia, C. (1994). Anaerobic digestion of straw and piggery waste waters. II. Optimization of the process. Agrochim., 38: 195-203.

McCahey S., McMullan J.T. and Williams B.C. (2003). Consideration of spent mushroom compost as a source of energy. Dev. Chem. Eng. Mineral Process., 11 (1/2), pp. 43-53.
Mondal T., Datta J.K. and Mondal N.K. (2017). Chemical fertilizer in conjunction with biofertilizer and vermicompost induced changes in morphophysiological and biochemical traits of mustard crop. J. Saudi Soc. Agric. Sci., 16:135-44.

Mousa G.T., Abdul-Hafeez E.Y. and Ibrahim O.H. (2015). Response of gardenia plants grown under various growth media and ferrous sulfate application. Pakistan J. Agric. Sci., 52(3): 651-658.

Nagavallemma K.P., Stephane W.S.P., Stephane L., Padmaja V.V., Vineela C., Rao M. and Sahrawat K.L. (2004). Recycling wastes into valuable organic fertilizer. International crops Research Institute for the Semi-Arid Tropics, Telangana state, India: P.20.

Naz F., Jalal-ud- Duin B., Munir M. and Khakwani A.A. (2013). Growth and development response of antirrhinum to plant growing media. J. Appl. Hort., 15(1):32-37.

Pregl F. (1945). Quantitative Organic MicroAnalysis. $4^{\text {th }}$ Ed. J. and A. Churchill, Ltd., London,UK.

Putra E., Sudirman A. and Indrawati W. (2016). The effect of organic fertilizer on the vegetative growth of sugarcane variety of GMP 2 and GMP 3. AIP J., 4(2): 60-68.

Rahmad A., Asrul L., Kuswinanti T. and Musa Y. (2019). The effect of sugarcane bagasse and filter mud compost fertilizer and manure application on the growth and production of sugarcane. Int'l. J. Sci. Res. Sci. Technol., 6(6):338-345.

Roy S., Shibu B., Chakraborty U. and Chakraborty B. (2015). Evaluation of spent mushroom substrate as bio-fertilizer for growth improvement of Capsicum annuиm L. J. Appl. Biol. and Biotech., 3(3):022-027.

Savvas D. and Gruda N. (2018). Application of soilless culture technologies in the modern greenhouse industry-A review. Eur. J. Hortic. Sci., 83, 280-293.

Sayed I.H. (2004). Response of Gladiolus Plants to Some Bio- and Chemical Fertilization. Ph.D. Thesis, Fac. Agric., Minia Univ. 209pp.

Schroeder F. G. and Sell H. (2009). Use of compost made from livestock manure as an organic substrate for cucumber (Cucumis sativus L.) grown in 
greenhouse- Acta Horticulturae, 819: 367-372

Shrestha U., Rosskopf En. and Butler Dm. (2018). Effect of anaerobic soil disinfestation amendment type and $\mathrm{C}: \mathrm{N}$ ratio on Cyperus esculentus tuber sprouting, growth and reproduction. Weed Res., 58: 379-388.

Siddiqui Y., Islam T. M., Naidu Y. and Meon S. (2011). The conjunctive use of compost tea and inorganic fertilizer on the growth, yield and terpenoid content of (Centella asiatica L.) urban. Sci. Hort., 130: 289295.

Snedecor G.W. and Cochran W.G. (1980). Statistical Methods. $7^{\text {th }}$ ed. The Iowa State Univ. Press. Ames., Iowa, U.S.A., pp. 593.

Snell F.D. and Snell C.T. (1967). Colorimeteric Method of Analysis. D. van Nestrant Company Inc., Lincoln, Lincolnshire, United Kingdom P. 551-552.

Soliman T.M.A., El-Keltawi N.E., Khan M.A., Nan M. and Zhao L.J. (2013). Plant growth and flowering of cape jasmine (Gardenia jasminoides, Ellis) in various substrates amended with sulphur. Global J. Plant Ecophysiol., 3(2): 36-43.

Steel R.G. and Torrie J.H. (1980). Reproduced from principles and procedures of statistics. Printed with the permission of C. I. Bliss, pp. 448-449.

Taha M., Salama A., EL-Seedy M., EL-Akhdar I., Islam M. S., Barutcular C. and El Sabagh A. (2016). Potential impact of compost tea on soil microbial properties and performance of radish plant under sandy soil conditions - greenhouse experiments. Aust. J. Basic and Appl. Sci., 10(8): 158-165.
Tao W., Zhang H., Xue W., Ren L., Xia B., Zhou X., Wu H., Duan J. and Chen G. (2014). Optimization of supercritical fluid extraction of oil from the Gardenia jasminoides and its antidepressant activity. Mol., 19:19350-19360.

Tejada M. and Benítez C. (2015). Application of vermicomposts and compost on tomato growth in greenhouses. Compost Sci. Util., 23:94-103.

Van Den Heuvel K., Van Lipzig R.H., Barendse G.W. and Wullems G.J. (2002). Regulation of expression of two novel flower-specific genes from tomato (Solanum lycopersicum) by gibberellin. J. Exp. Bot., 53(366):51-9.

Westein D. V. (1957). Chlorophyll-lethal and the submicroscopic shape change of the plastids. Experiment. Cell Res., 12:427.

Wiafe-Kwagyan M. and Odamtten G.T. (2018). Use of Pleurotus eous strain P-31 spent mushroom compost (SMC) as soil conditioner on the growth and yield performance of Capsicum annuum $\mathrm{L}$. and Solanum lycopersicon L. seedlings under greenhouse conditions in Ghana. Tropi.Life Sci. Res., 29(1): 173-194.

Wu S., Wang G., Liu Z., Rao J., Lv L., Xu W., $\mathrm{Wu}$ S. and Zhang J. (2009). Effect of geniposide, a hypoglycemic glucoside, on hepatic regulating enzymes in diabetic mice induced by a high-fat diet and streptozotocin. Acta Pharmacol. Sin., 30 (2): 202-208.

Yang B., Liu X. and Gao Y. (2009). Extraction optimization of bioactive compounds (crocin, geniposide and total phenolic compounds) from gardenia (Gardenia jasminoides Ellis) fruits with response surface methodology. Innov. Food Sci. Emerg. Technol., 10:610-615. 
استجابة نباتات الجاردينيا جاسمينويدز النامية في أوساط مختلفة لمحسنات عضوية

$$
\begin{aligned}
& \text { فوزية غريب زنة - يحيى ابراهيم محمود * }
\end{aligned}
$$

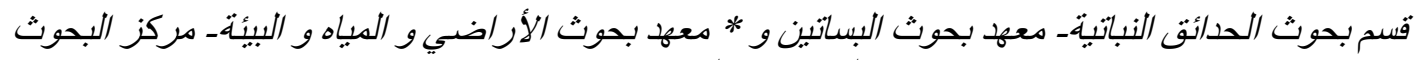

$$
\begin{aligned}
& \text { الزراعبة الجيزة- مصر }
\end{aligned}
$$

ملخص

أجرى هذا البحث لمدة موسمين متتاليين (2017، 2018) لتقييم فعالية مستخلصات الكمبوست المجهز من مصادر

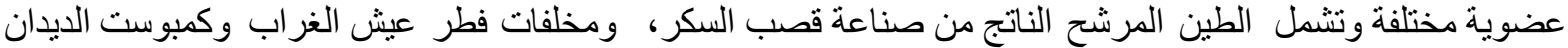

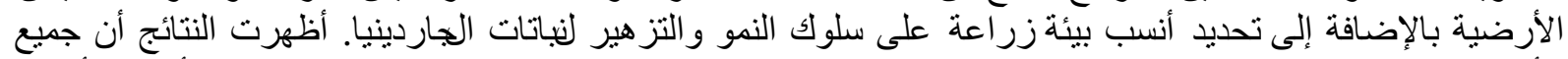

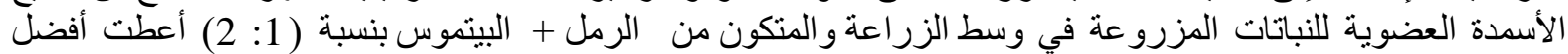

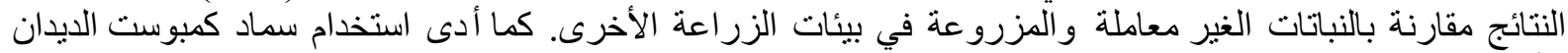

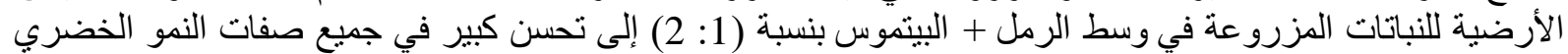

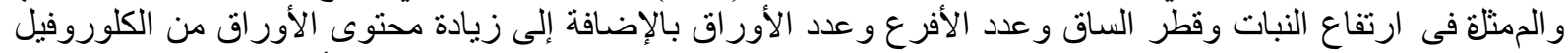

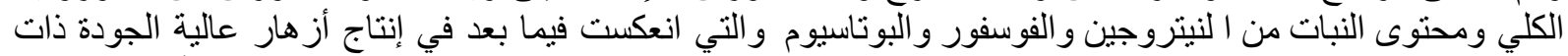

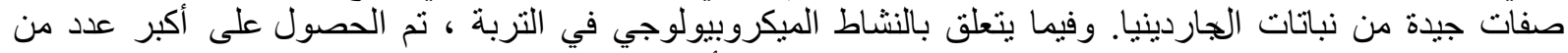

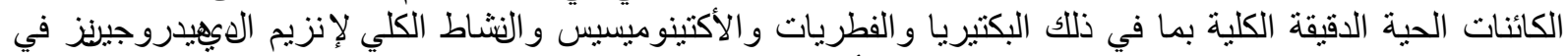
منطقة الجذور نتيجة استخدام سماد كمبوست الديدان الأرضية للنباتات المزروعة في وسط الرمل + البيتموس بنسبة (1: (2 $)$ حجما.

المجلة العلمية لكلية الزراعة - جامعة القاهرة ـ المجلد (71) العدد الثالث (يوليو2020): 157-173 ـ 